\title{
Interactive Teaching Materials as an Alternative to Overcome Difficulties of Reading and Writing Beginning for Primary 1 Grade Students
}

\author{
Riptina Pawestri ${ }^{1}$, Kuntoro $^{2}$, Desy Prastiti Setiarini ${ }^{3}$, Upik Aimanah ${ }^{4}$ \\ \{ $\underline{\text { riptina.2305@gmail.com }}$, kuntorosutaryo@gmail.com ${ }^{2}$, ibunefarhan@gmail.com ${ }^{3}$, \\ upik.aima@gmail.com ${ }^{4}$ \} \\ ${ }^{1}$ SDN 1 Bancarkembar \\ ${ }^{2}$ Universitas Muhammadiyah Purwokerto \\ ${ }^{3}$ SDN 1 Kejobong \\ ${ }^{4}$ SDN 1 Karangnangka
}

\begin{abstract}
The research aims to see the use of interactive teaching materials as an alternative to overcoming the difficulties of reading and writing on the beginning of grade 1 elementary school students. Teaching materials are a source of learning in learning activities. Teaching materials can be in the form of text books, digital books, digital applications, and so on. The type of data used is secondary data. The method used in this research is literature study method. The research periode is from March to May 2021. The data obtained were compiled, analyzed, and concluded in order to get conclusions about the literature study. Based on the results of research, literature studies from several research results and journal articles show that the use of interactive teaching materials can overcome the difficulty of reading and writing beginning of grade 1 elementary school students.
\end{abstract}

Keywords: interactive teaching materials, difficulty reading and writing pre-beginnings, elementary school

\section{Introduction}

Learning as an activity for students in class requires good planning. As well as learning in first grade for introductory reading and writing material. This material is the material that becomes the basis for initial knowledge before students understand the next material. Learning to read and write beginning in grade one really requires careful planning. This planning, apart from the learning steps to be carried out, also includes planning in preparing teaching materials. The preparation of good teaching materials is certainly not only about preparing existing teaching materials, but requires various considerations. Some things that must be considered in preparing teaching materials include students' readiness to learn, interest in learning, and student profiles. Teaching materials are a source of learning in learning activities. Teaching materials can be in the form of text books, digital books, digital applications, and so on. Good teaching materials are teaching materials that are developed on the basis of the learning needs of students, the characteristics of students' learning and the characteristics of the learning environment [1].

Teaching and learning activities occur when there is an interaction between students and the learning environment set by the teacher to achieve teaching goals. The classic problem in learning to read and write introductions for first grade students is the use of conventional teaching materials. Conventional teaching materials are standard teaching materials and are limited to presenting only simple text and images[2]. The problem of using conventional 
teaching materials makes it difficult for students to understand teaching materials. Based on the results of the literature review, the writer found the right alternative to overcome the learning difficulties of students in reading and writing at the beginning.

Based on the initial condition data before using interactive teaching materials, only 12 out of 25 students obtained learning outcomes more than or equal to the KKM. The problem of using conventional teaching materials makes it difficult for students to understand teaching materials. The problem studied in this research is the extent to which the effectiveness of using interactive teaching materials on early reading and writing skills is? The aims of this study was to determine the effectiveness of interactive teaching materials on early reading, and writing skills. It is hoped that this literature study can contribute to educators in choosing effective teaching materials for early reading and writing learning.

Learning material for introductory reading and writing is material in first grade of elementary school. Preliminary reading learning is divided into two stages, namely: learning to read without books and learning to read using books. Preliminary writing learning is also divided into two stages, namely: the letter recognition stage and writing training. Reading and writing beginnings are basic and important for students to master before learning other material. After being able to read and write, then students have no difficulty in learning existing learning materials.

Advanced reading skills are skills to read precisely, quickly and understand the text they read. Briefly and simply explain that reading for first grade elementary school students is an activity of the process of matching letters or pronouncing symbols of written or reading language is the process of recording and decoding [3]. As a skill that underlies the next skill, the initial reading skills really need the attention of the teacher, because if the foundation is not strong, at the initial reading stage the child will have difficulty being able to have adequate initial reading skills[4]. Reading is a process of obtaining information and reconstructing the meaning contained in the text. The message contained in the text is an active and dynamic interaction between the reader's abilities and the sentences contained in the text.

In addition to the ability to read preface, the ability to write early on is also important. Writing is an orderly thought process in expressing ideas, thoughts and feelings in writing so that it is easily understood by readers[5]. Writing skills are one of the language skills, including listening, speaking, reading, and writing[6]. Writing requires accuracy, patience, persistence and the ability to seek and find ideas, ideas that can be put into writing. Based on the description above, it can be concluded that introductory writing is a process of expressing ideas, thoughts, and feelings into a language of symbols that the reader can understand.

Reading the beginning and writing the introduction are activities that cannot be separated. In pre-reading reading and writing skills in first grade the teacher can make efforts, including providing additional tutorials, presenting reading books, using study time well, dictating students, using the spelling reading method and reading fluently [7]. Both language skills can be practiced simultaneously and both support each other. When students write letters, syllables, words, and sentences, of course, they also go through the symbol reading stage. After learning to read, students need to learn how to write. Likewise, when students learn to write letters, syllables, words, sentences, students also learn how to read them. Almost the same as the Whole Language approach which emphasizes reading and writing activities starting from a complete and inseparable form[5].

Based on the background description and literature review, a suitable alternative for overcoming pre-reading and writing difficulties in first grade elementary school students is the use of interactive teaching materials. Interactive teaching materials are teaching materials that attract students' learning interest[8]. Based on the results of a literature review conducted in March - 
May 2021, the author sees an alternative to overcome the difficulties of early reading and writing.

\section{Research Methods}

This research is a literature review research. The data taken in this study is secondary data. Secondary data is data taken not from direct observers but from the results of research by previous researchers. The data collection method used in this research is the documentation method. The documentation method is a systematic data collection procedure for reviewing both printed and electronic documents [9].

The study idea was obtained by comparing the conditions in the field with ideal conditions. The idea of the study started from the lack of implementation of interactive teaching materials where students seemed less enthusiastic in participating in the initial reading and writing lessons. So the author made the title "Interactive Teaching Materials as an Alternative to Overcome Difficulties of Reading and Writing Beginning for Primary 1 Grade Students."

The purpose of the literature study is to increase understanding of the research idea. The literature sources used include international journals, Indonesian journals, and text books related to the topics discussed in the research.

The results and discussions in this literature study are: 1) Explaining the conditions of learning to read and write the beginning before using interactive teaching materials; 2) Seeing the effectiveness of the use of interactive teaching materials in learning to read and write beginning.

The documentation method is a data collection method by finding or extracting data from literature related to what is meant in the problem formulation. The data analysis used in this research is bibliographic annotation analysis. Annotation means a simple conclusion from an article, book, journal, or some other written source, while a bibliography is defined as a list of sources on a topic[10].

\section{Result and Discussion}

The results of the study were based on the collected research data showing that through the use of interactive teaching materials it can overcome the difficulties of reading and writing beginning of first grade elementary school students. As the research results show that through interactive teaching materials it can improve students' reading and writing skills[11].

The results of the other research regarding interactive teaching materials were also conveyed to improve the creative thinking skills of students[12]. Through the use of interactive teaching materials in learning, it can be motivation to learn for students[13]. Interactive teaching materials trigger students to have critical thinking skills[14].Interactive teaching materials can improve the quality of the process and the learning outcomes of introductory reading and writing skills[15]. Teaching materials developed must be in accordance with pedagogical quality so that they are effective and attractive to students, effective for teachers in the learning process and learning objectives [16-17].

The effectiveness of the use of interactive teaching materials can be seen from the increase in student learning outcomes in early reading and writing learning. The improvement is seen based on research data before using interactive teaching materials, only 12 out of 25 students are more than or equal to the KKM. After using interactive teaching materials, student learning outcomes increased with the number of students who scored more than or equal to the KKM as many as 23 students.

Based on the description in the introduction and discussion, it can be concluded that teaching materials are very important elements for teachers to prepare in learning. Because it is important that the teaching materials must be prepared as well as possible. This teaching 
material is designed to meet the learning needs of students which include learning readiness, interest in learning and student learning profiles. This fulfillment can be seen from the interactive textbooks in terms of content and context.

\section{Conclusions}

Based on the background of the problem and the results of the literature research presented, it can be concluded that through the use of interactive teaching materials it is effective to improve early reading and writing skills. Interactive teaching materials have proven to be an alternative to overcome reading and writing difficulties for first graders of elementary school. The author hopes that this paper can be an alternative study for teachers and related parties in overcoming the difficulties of reading and writing for the first graders of elementary school.

\section{Reference}

[1] Mardhatillah M, Verawati V, Evianti E, Pramuniati I. Bahan Ajar Interaktif Berbasis Kearifan Lokal Melalui Pendekatan Saintifik Pada Pembelajaran Bahasa Inggris. Genta Mulia: Jurnal Ilmiah Pendidikan. 2019 Jan 2;10(1).

[2] PRIHANTANA MA, Santyasa IW, Warpala IW. Pengembangan Bahan Ajar Interaktif Berbasis Pendidikan Karakter Pada Mata Pelajaran Animasi Stop Motion untuk Siswa SMK. Jurnal Teknologi Pembelajaran Indonesia. 2014 Aug 19;4(1).

[3] Nirmala SD. Kemampuan Berpikir Kritis Siswa Kelas Iv Se-Gugus 2 Purwasari Dalam Membaca Pemahaman Melalui Model Fives Dan Model Guided Reading. Dinamika Jurnal Ilmiah Pendidikan Dasar. 2019 Feb 12;10(2).

[4] Muhyidin A, Rosidin O, Salpariansi E. Metode pembelajaran membaca dan menulis permulaan di kelas awal. JPsd (Jurnal Pendidikan Sekolah Dasar). 2018 Mar 29;4(1):3042.

[5] Suastika NS. Problematika Pembelajaran Membaca dan Menulis Permulaan di Sekolah Dasar. Adi Widya: Jurnal Pendidikan Dasar. 2019 Jul 22;3(1):57-64.

[6] Khoridah F, Prasetiyawati D, Baedowi S. Analisis Penerapan Metode SAS (Struktural Analitik Sintetik) Dalam Kemampuan Menulis Permulaan. Journal for Lesson and Learning Studies. 2019;2(3):396-403.

[7] Fauziah H. Upaya Guru dalam Mengembangkan Kemampuan Membaca Menulis Permulaan Siswa Kelas I MI. Elementary: Jurnal Ilmiah Pendidikan Dasar. 2018 Dec 3;4(2):173-84.

[8] Fajarwati N. Media Pembelajaran Video Interaktif terhadap Peningkatan Keterampilan Membaca Permulaan Siswa Tunagrahita ringan. Jurnal Pendidikan Khusus. 2015 Apr $19 ; 7(2)$.

[9] Bowen GA. Document analysis as a qualitative research method. Qualitative research journal. 2009 Aug 3.

[10] Arsyillah BT, Muhid A. Pendidikan Multikultural Dalam Membentuk Karakter Pemuda Di Perguruan Tinggi. Al-Fikr: Jurnal Pendidikan Islam. 2020 Aug 1;6(1):17-26.

[11] Herman S, Muhdiah M. Sistem Interaktif Membaca Permulaan bagi Anak Usia Dini. ILKOM Jurnal Ilmiah. 2016 Apr 30;8(1):23-8.

[12] Rachmawati F, Kirana T, Widodo W. Buku ajar interactive book untuk meningkatkan kemampuan berpikir kreatif siswa sekolah dasar. Jurnal Penelitian Pendidikan IPA. 2018 Jul 9;2(1):19-29.

[13] Abadi MK, Pujiastuti H, Assaat LD. Development of teaching materials based interactive scientific approach towards the concept of social arithmetic for junior high school student. 
In Journal of Physics: Conference Series 2017 Feb 1 (Vol. 812, No. 1, p. 012015). IOP Publishing.

[14] Wahyuni S, Erman E, Sudikan S, Jatmiko B. Edmodo-based interactive teaching materials as an alternative media for science learning to improve critical thinking skills of junior high school students.

[15] Febriyani A. Peningkatan Keterampilan Membaca Dan Menulis Permulaan Dengan Alat Peraga Kartu Huruf Pada Anak Kelompok A Tk Dharma Wanita V Baturan, Colomadu, Karanganyar Tahun Ajaran 2011/2012..

[16] Koper R, Tattersall C, editors. Learning design: A handbook on modelling and delivering networked education and training. Springer Science \& Business Media; 2005 Feb 18.

[17] Rohmah TR. Membangun Kearifan Lokal melalui Gerakan Literasi Mibanda (Micinta Baca Tulis Aksara Sunda) di SDN Sukahayu Kabupaten Subang. Dinamika Jurnal Ilmiah Pendidikan Dasar. 2019 Feb 12;10(2). 